\title{
Cuscohoplininus pagoreni: a new genus and species of Hoplinini stilt bug from Peru (Heteroptera: Berytidae)
}

Pablo M. Dellapé \& Diego L. Carpintero

División Entomología, Facultad de Ciencias Naturales y Museo, Universidad Nacional de La Plata, Paseo del Bosque s/n, 1900 La Plata, Argentina; pdellape@fcnym.unlp.edu.ar; dcarpint@fcnym.unlp.edu.ar

Received 12-I-2006. Corrected 17-X-2006. Accepted 30-I-2007.

\begin{abstract}
The Berytidae or stilt bugs are a cosmopolitan family of lygaeoid bugs, which are slender, elongate insects, with generally cylindrical bodies and very long, slender antennae and legs. Members of the tribe Hoplinini are characterized by the lack of a distinct metapleural scent channel and the possession of a dorsally directed process on the caudal edge of the male genitalia capsule (absent in Xenoloma and Cuscohoplininus). In this paper, we described the new genus and species Cuscohoplininus pagoreni from Peru. Scanning electron micrographs are provided to illustrate taxonomically important structures. Among the eight genera known in the tribe Hoplinini, the new genus Cuscohoplininus resembles Parajalysus in general aspect and size, but can be easily distinguished by the following characters: Parajalysus is characterized by the four large, erect pronotal spines, one centered on the anterior lobe, and on the posterior lobe, one at each humeral angle and one at the base of the meson; whereas, Cuscohoplininus has a single spine on the anterior pronotal lobe, an elongate scutellar spine (a tubercle is present in Parajalysus), and lacks a process on the caudal edge of the male genitalia capsule. Rev. Biol. Trop. 55 (2): 673-676. Epub 2007 June, 29.
\end{abstract}

Key words: Heteroptera, Berytidae, new genus, new species, Peru.

The Berytidae or stilt bugs are a cosmopolitan family of lygaeoid bugs. Berytids are slender, elongate insects, with generally cylindrical bodies and very long, slender antennae and legs. This family has phylogenetic affinities with the Cymidae, Ninidae, Colobathristidae and Malcidae (Henry 1997a, b).

Henry (1997a) provided a phylogenetic analysis of berytid genera of the world in which he proposed a major rearrangement of the intrafamilial classification, recognizing three subfamilies: Berytinae, Metacanthinae and Gampsocorinae. The Gampsocorinae include the Eastern Hemisphere tribe Gampsocorini and the Western Hemisphere tribe Hoplinini which comprises eight New World genera. The members of Hoplinini are characterized by the lack of a distinct metapleural scent channel and the possession of a dorsally directed process on the caudal edge of the male genitalia capsule (absent in Xenoloma and Cuscohoplininus). In this paper, we describe a new genus and species of this tribe from Peru.

\section{MATERIALS AND METHODS}

The material examined belongs to the collection of Museo de Ciencias Naturales de La Plata, Buenos Aires, Argentina (MLP). Scanning electron micrographs were made from a specimen mounted on a stub, sputter coated with a gold palladium alloy, and studied with a JEOL T-100 SEM. 


\section{RESULTS}

\section{Cuscohoplininus new genus}

Diagnosis: This genus is easily distinguishable from the other Hoplinini by the presence of only one pronotal spine centered on the anterior lobe.

Description: Medium sized (Total length: 5.52-6.42 mm). Head smooth, impunctate, eyes relatively small, postocular distance at least twice as long as eye length. Ocelli widely set behind eyes, near anterior margin of pronotum. Vertex convex. Antennae long, slender, segment one longest, segments two and three subequal in length, and segment four shortest and fusiform. Pronotum strongly convex, longer than wide, with two distinct lobes, lateral margins with a low carina; anterior lobe basally smooth and anteriorly punctate, armed with one short spine medially; posterior lobe unarmed, distinctly punctate, with a median carina. Scutellum armed with one long spine. Hemelytra hyaline, translucent, yellowish. Propleura punctate. Pro- and mesosternum with wide smooth median (rostral) groove. Ostiolar evaporative area restricted to upper half of the mesopleuron. Abdomen smooth, shiny. Caudal edge of male genitalia capsule lacking a dorsally directed process.

Etymology: The generic name is composed by "Cusco" the department of Peru where the specimens were collected, and the tribal name Hoplinini.

\section{Cuscohoplininus pagoreni $n . s p$.}

Description: Holotype male: Length 5.66 $\mathrm{mm}$. General coloration pale brown; subglabrous. Head (Fig. 1, 2): Length $0.6 \mathrm{~mm}$, width $0.55 \mathrm{~mm}$; vertex $0.32 \mathrm{~mm}$. Rostrum: reaching middle of mesosternum; ventrally darker than dorsum. Antenna: Segment I, length $4.95 \mathrm{~mm}$; II, $2.45 \mathrm{~mm}$; III, $3.00 \mathrm{~mm}$; IV 0.84 $\mathrm{mm}$; uniformly dark brown; segments I, II and III weakly clavate; segment IV fusiform. Pronotum (Fig. 1, 4): Length $1.13 \mathrm{~mm}$, basal width 0.92 . Scutellum (Fig. 3): with slender spine, $0.25 \mathrm{~mm}$ long. Hemelytron: macropterous, elongate, exochorium narrow and elongate, extending to sixth abdominal segment; membrane translucent, finely spotted. Ventral surface: pale brown, impunctate, abdomen smooth and shining. Ostiolar evaporative area (Fig. 4): reduced, subtriangular. Legs: Femora pale brown with numerous dark brown spots, subapically darker without spots; with short sparse setae. Tibiae dark brown, with short sparse setae. Femoral lengths: Pro- $3.26 \mathrm{~mm}$; meso- 3.58 $\mathrm{mm}$; meta- $5.21 \mathrm{~mm}$. Tibial lengths: Pro- 3.58 $\mathrm{mm}$; meso- $4.16 \mathrm{~mm}$; meta- $7.26 \mathrm{~mm}$. Genital capsule (Fig. 5, 6): elongate, subtriangular.

Measurements of male paratype: Length $5.74 \mathrm{~mm}$. Head: Length $0.68 \mathrm{~mm}$, width 0.59 $\mathrm{mm}$; vertex $0.34 \mathrm{~mm}$. Antenna: Segment I, length $4.47 \mathrm{~mm}$; II, $2.16 \mathrm{~mm}$; III, $2.68 \mathrm{~mm}$; IV, $0.77 \mathrm{~mm}$. Pronotum: length $1.19 \mathrm{~mm}$, basal width $1.01 \mathrm{~mm}$. Scutellar spine $0.3 \mathrm{~mm}$ long. Legs: Femoral lengths: Pro- $2.71 \mathrm{~mm}$; meso$3.32 \mathrm{~mm}$; meta- $4.68 \mathrm{~mm}$. Tibial lengths: Pro$3.21 \mathrm{~mm}$; meso- $3.95 \mathrm{~mm}$; meta- $7.00 \mathrm{~mm}$.

Female $(n=6)$ : Length 5.52-6.42 mm (mean $5.92 \mathrm{~mm}$ ). Head: Length 0.63-0.75 $\mathrm{mm}$ (mean $0.70 \mathrm{~mm}$ ), width $0.54-0.58 \mathrm{~mm}$ (mean $0.57 \mathrm{~mm}$ ); vertex $0.34-0.37 \mathrm{~mm}$ (mean $0.36 \mathrm{~mm})$. Antenna: Segment I, length 4.45$4.68 \mathrm{~mm}$ (mean $4.53 \mathrm{~mm}$ ); II, 2.21-2.32 mm (mean $2.25 \mathrm{~mm}$ ); III, 2.68-2.89 mm (mean $2.78 \mathrm{~mm}$ ); IV, 0.79-0.84 mm (mean 0.82 $\mathrm{mm}$ ). Total length 10.15-10.69 mm (mean $10.39 \mathrm{~mm}$ ). Pronotum: Length 1.15-1.26 mm (mean $1.20 \mathrm{~mm}$ ), basal width $1.15-1.26 \mathrm{~mm}$ (mean $1.20 \mathrm{~mm}$ ) Scutellar spine 0.26-0.32 $\mathrm{mm}$ (mean $0.29 \mathrm{~mm}$ ). Legs: Femoral lengths: Pro- 2.95-3.05 mm (mean $3.00 \mathrm{~mm}$ ); meso3.37-3.58 mm (mean $3.47 \mathrm{~mm}$ ); meta- 4.68$5.16 \mathrm{~mm}$ (mean $4.92 \mathrm{~mm}$ ). Tibial lengths: Pro- 3.21-3.42 mm (mean $3.32 \mathrm{~mm}$ ); meso3.82-4.03 mm (mean $3.93 \mathrm{~mm}$ ); meta- 7.21$7.58 \mathrm{~mm}$ (mean $7.42 \mathrm{~mm}$ ).

Very similar to male in all aspects.

Host: Unknown.

Distribution: Peru, Cusco, rainforest.

Etymology: The specific epithet pagoreni refers to the small town and homonymous river where the holotype was collected. 

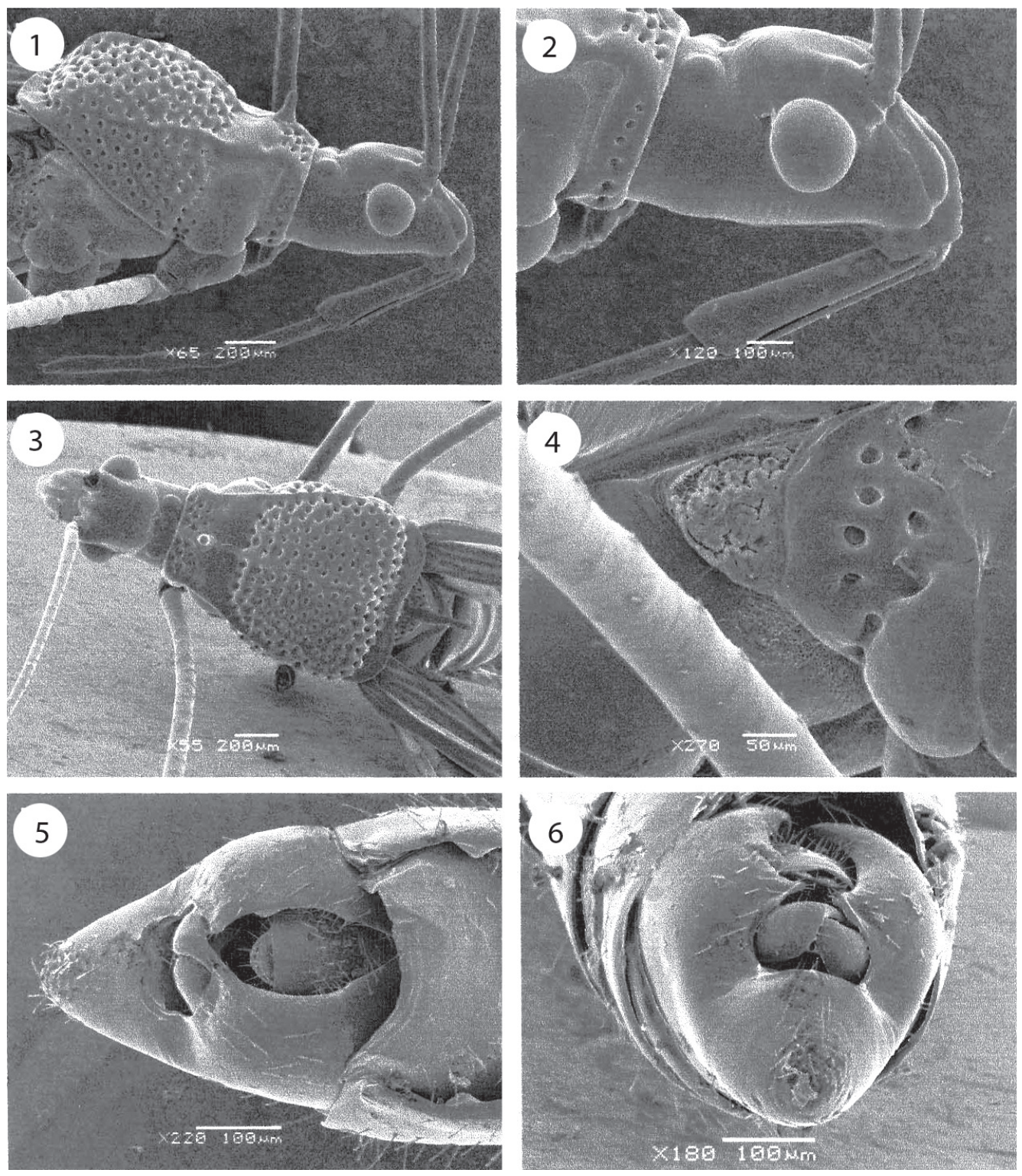

Figs. 1-6. Cuscohoplininus pagoreni n. sp. Fig. 1. Head and pronotum, lateral view. Fig. 2. Head, lateral view. Fig. 3. Head, pronotum and scutellum, dorsal view. Fig. 4. Ostiolar evaporative area. Fig. 5. Male genital capsule, dorsal view. Fig. 6. Male genitalia, caudal view.

Type data: Holotype: male, Peru: Cusco, Pagoreni, VII-(20)04, Williams, luz, 72 $54^{\prime} 07^{\prime \prime}$ W 11 ${ }^{\circ} 42^{\prime} 22^{\prime \prime}$ S (MLP). Paratypes: 4 females, same data. 1 male, 2 females, Peru: Nuevo Mundo, Base Pluspetrol, VII-(20)04, J. Williams, luz, $73^{\circ} 08^{\prime} 30^{\prime \prime} \mathrm{W} 11^{\circ} 33^{\prime} 02^{\prime \prime} \mathrm{S}$ (MLP).

\section{DISCUSSION}

Acording to Henry's (1997a) phylogenetic hypothesis, the Hoplinini can be divided into two clades: one including Hoplinus Stål, Phaconotus Harris, Oedalocanthus Henry and 
Pronotacantha Uhler that possess a ventrally extended evaporative area, and a second clade comprising Diabolonotus Henry, Xenoloma Harris, Metajalysus Stusak and Parajalysus Distant with ostiolar area reduced to a circular swollen area near the middle of metapleural area. The reduced ostiolar area of Cuscohoplininus permits us to assign it to the latter clade.

This new genus resembles Parajalysus in general aspect and size (Parajalysus and Cuscohoplininus being the only two genera longer than $5 \mathrm{~mm}$ ). Parajalysus is characterized by the four large, erect pronotal spines, one centered on the anterior lobe, and on the posterior lobe, one at each humeral angle, and one at the base of the meson; whereas Cuscohoplininus has a single spine on the pronotum, on the anterior pronotal lobe, an elongate scutellar spine (a tubercle is present in Parajalysus), and lacks a process on the caudal edge of the male genitalia capsule.

Cuscohoplininus runs to couplet 7 in Henry's key to Hoplinini genera of the Western Hemisphere (Henry 1997c); this couplet identifies Phaconotus and Oedalocanthus, but Cuscohoplininus can be easily distinguished from both genera by the absence of rounded tubercles on the pronotum.

\section{ACKNOWLEDGMENTS}

Our gratitude goes to Pluspetrol Perú Corporation, S.A. and ERM Perú, S.A. for financial support of the fieldwork that was carried out during the environmental impact assessment of block 56 in Pagoreni and Nuevo Mundo, Cusco. This work was funded by the Consejo Nacional de Investigaciones Científicas y Técnicas (CONICET), Argentina.

\section{RESUMEN}

La familia Berytidae es cosmopolita y está integrada por chinches alargadas, con cuerpo generalmente cilíndrico y con antenas y patas muy largas. Los miembros de la tribu Hoplinini se caracterizan por carecer de canal la glándula repugnatoria y por poseer un proceso caudal dirigido dorsalmente sobre el borde posterior de la cápsula genital masculina (ausente en Xenoloma y Cuscohoplininus). Describimos un nuevo género y especie: Cuscohoplininus pagoreni de Perú. Se tomaron fotografías de microscopia electrónica para ilustrar estructuras de importancia taxonómica. Entre los ocho géneros conocidos de la tribu Hoplinini, Cuscohoplininus n. gen. es similar al género Parajalysus en aspecto general y en tamaño. Sin embargo, puede distinguirse así: Parajalysus se caracteriza por poseer cuatro grandes espinas erectas sobre el pronoto, una en el centro del lóbulo anterior, una en cada ángulo humeral y, la cuarta, también sobre el lóbulo posterior sobre el margen posterior; por otro lado Cuscohoplininus tiene una sola espina sobre el pronoto situada sobre el lóbulo anterior, una espina escutelar (Parajalysus presenta solo un tubérculo sobre el escutelo) y carece de proceso caudal.

Palabras clave: Heteroptera, Berytidae, nuevo género, nueva especie, Perú.

\section{REFERENCES}

Henry, T.J. 1997a. Cladistic analysis and revision of the stilt bug genera of the world (Heteroptera: Berytidae). Contr. Am. Entomol. Inst. 30: 1-100.

Henry, T.J. 1997b. Phylogenetic analysis of family groups within the infraorder Pentatomomorpha (Hemiptera: Heteroptera), with emphasis on the Lygaeoidea. Ann. Entomol. Soc. Am. 90: 275-301.

Henry, T.J. 1997c. Monograph of the stilt bugs, or Berytidae (Heteroptera), of the Western Hemisphere. Mem. Entomol. Soc. Wash. 19: 1-149. 